\title{
Relationship of Child Individual Factors with Stunting Incidence in Children Aged 24-36 Months at Serdang Bedagai District
}

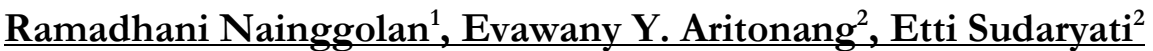 \\ ${ }^{1}$ Master Student in Faculty of Public Health, Universitas Sumatera Utara, Medan, Indonesia \\ ${ }^{2}$ Lecturer in in Faculty of Public Health, Universitas Sumatera Utara, Medan, Indonesia \\ Email: ramadhaninainggolan5@gmail.com
}

\begin{abstract}
:
Stunting is a form of malnutrition, as a proportion of children under 5 years old whose height is below minus 2 standard deviations based on the WHO Child Growth Standards. The purpose of the study was to determine the relationship of individual child factors with the incidence of stunting of children aged 24-36 months in Serdang Bedagai District, Sumatera Utara Province, Indonesia. This type of research is a case control study. The sample of this study amounted to 120 toddler, namely 60 cases and 60 controls with cluster sampling technique. Data was collected by interview technique using a questionnaire, and stunting data is determined by anthropometric measurements. Data analysis used chi-square test with $a=5 \%$. The result showed that breastfeeding history, birth weight and birth length were related to the incidence of stunting in children aged 24-36 months ( $p<0,05 ; O R=2.1$ ). It is suggested that there will be cooperation from various parties in overcoming nutritional problems during pregnancy and breastfeeding periods, such as increasing attention in the first 1000 days of human life, attention to nutrition of pregnant women as prevention of low birth weight and low birth length, which in turn affects stunting, as well as attention increase breastfeeding in infants.
\end{abstract}

Keywords:

stunting; breastfeeding; birth weight; birth length

\section{Introduction}

Stunting in children under five years is a description of low height-for-age, and one of the most commonly used growth indices for children. Another index is weight-for-age and weightfor-height. Stunting is determined based on the WHO child growth standard reference, which is height-for-age below minus 2 standard deviations (WHO, 2019). Trends and levels of malnutrition in children around 155 million. The prevalence of stunting for children under 5 years is 22.9 percent or 154.8 million globally in 2016. The stunting rate exceeds 30 percent in children under 5 years in Africa (31.2\%), Asia (23.9\%)) and Oceania (38.3) (WHO, 2017).

Based on the results of Indonesia's national survey in 2013, namely RISKESDAS, the prevalence of stunting on children under five years in Indonesia was 37.2\%, an increase compared to $2010(35.6 \%)$ and 2007 (36.8\%). But in 2018 it decreased to 30.8\%. Compared to several neighboring countries, the prevalence of stunting on toddlers in Indonesia is also highest compared to Myanmar (35\%), Vietnam (23\%), Malaysia (17\%), Thailand (16\%) and Singapore (4\%) (UNSD, 2014). Based on the Global Nutrition Report in 2014 shows that Indonesia is included in 17 countries, among 117 countries, which have three nutritional problems, namely stunting, wasting and overweight in infants (KEMENKES, 2016).

The prevalence of stunting in children was highest at aged of 24-35 months (42.0\%) and decreased at the age of $36-47$ months. Stunting is more common in boys (38.1\%) compared to 
girls $(36.2 \%)$. Rural areas have a higher prevalence of stunting $(42.1 \%)$ than urban areas $(32.5 \%)$. According to the level of ownership or economic strata in the population, stunting is more common among those in the lowest quintile (RISKESDAS, 2013).

One risk factor that affects the incidence of stunting in children under five is a history of birth weight. Pregnant women with underweight are at risk of be deliver babies of low birth weight (LBW), if not treated properly will be at risk of stunting. LBW (less than 2,500 grams) will carry the risk of death, disturbance of child growth and development, including stunting (KEMENKES, 2016). Birth length represents the linear growth of the baby during the womb. Low linear size usually indicates a lack of nutrition due to a lack of energy and protein that was suffered in the past (Supariasa et al., 2012). The results of Riskesdas in 2013 showed the percentage of short-born babies (birth length $<48 \mathrm{~cm}$ ) is $20.2 \%$ (Ministry of Health, 2013). Birth length affects the growth of infants in the growth period.

Infant growth will be good if given exclusive breastfeeding for 6 months because breast milk can meet baby's nutrition. Breast milk also increases the baby's immunity, and reduces the risk of infectious diseases. After 6 months of age, besides breastfeeding, complementary foods are given. Growth and development of infants who are exclusively breastfed will not experience growth disturbances in body weight and length, compared to infants who are not exclusively breastfed, babies will be shorter (Fikawati, 2015).

Based on data from the Serdang Bedagai Health Office in 2017, the prevalence of stunting infants was $31.6 \%$, with short criteria of $16.3 \%$ and very short $15.3 \%$. The prevalence of stunting in toddlers is a public health problem if the prevalence is $20 \%$ or more. Therefore the percentage of toddlers stunting in Serdang Bedagai is high and is a health problem that must be overcome.

\section{Research Method}

This research is a quantitative study with case control design. The subjects of this study were children aged 24-36 months. Sampling was done by cluster sampling technique. The number of subjects was 120 children, which were divided into 2 groups, namely a case group was 60 children of stunting and a control group was 60 children with normal hight. Subjects taken for cases were from 6 villages that had malnutrition problems in toddler and subjects for control were taken from 6 villages with no cases of malnutrition. Criteria for inclusion of subjects were living in selected village areas and one house with parents, having parents (mothers and fathers) complete or not dying, willing to participate in this study, having the card of growth chart (KMS), coming four times to the post of integrated service (posyandu) in six consecutive months. This study, used the subject's mother as a respondent to be interviewed, to ask the child's data such as exclusive breastfeeding history, data on birth weight and length of birth.

The independent variable of this study was the incidence of stunting, the dependent variable was a child individual factor consisting of birth weight, birth length and exclusive breastfeeding. Data on the incidence of stunting was collected by measuring anthropometry of height, using a microtoa of height measurement, then adjust the measurement results with WHO Child Growth Standards. Data including birth weight, birth length and breastfeeding history were collected through interviews with questionnaire guidelines, and matched with the information in the card of growth chart (KMS). Data were analyzed univariately, and bivariately. Bivariate test to see the relationship is done by Chi Square test. 


\section{Discussion}

This study uses subjects in the case and control groups with the same ratio, which is 1: 1 , each group member consisting of 60 children. This study uses subjects in the case and control groups with the same ratio, which is $1: 1$, each group member consisting of 60 children. The selection of cases and controls was carried out without matching the age and sex of the child, because the height increase period for children aged 24-36 months based on the sex of the child was not much different.

The results showed that of the 120 children, there were 49 children, did not get exclusive breastfeeding $(40.8 \%)$. While there are 71 children were given exclusive breastfeeding $(59.2 \%)$.

Table 1. Distribution of Frequency of History of Breastfeeding in Children 24-36 Months

\begin{tabular}{clcc}
\hline Number & $\begin{array}{l}\text { Breastfeeding } \\
\text { history }\end{array}$ & $\begin{array}{c}\text { Amount } \\
(\mathrm{N})\end{array}$ & $\begin{array}{c}\text { Percentage } \\
(\%)\end{array}$ \\
\hline 1 & $\begin{array}{l}\text { Not } \\
\text { exclusive } \\
\text { breastfeeding }\end{array}$ & 49 & 40.8 \\
& $\begin{array}{c}\text { Exclusive } \\
\text { breastfeeding }\end{array}$ & 71 & 59.2 \\
\hline 2 & Total & 120 & 100 \\
\hline
\end{tabular}

Children who did not receive exclusive breastfeeding during the first 6 months of their lives experienced more stunting. Chi Square test results showed that there was a relationship between exclusive breastfeeding and the incidence of stunting $(\mathrm{OR}=2.1)$. These results are like Khoirun's study (2015) which also shows that toddlers who are not exclusively breastfed have a greater risk of stunting.

Exclusive breastfeeding can prevent stunting or failure to thrive (WHO, 2013). The content of lactoferrin in breast milk serves to bind iron to inhibit bacterial growth (IDAI, 2009). Research of Permadi et al. also showed that children who did not get exclusive breastfeeding had a significant relationship with the incidence of stunting. Children who do not get exclusive breastfeeding have a risk of experiencing stunting of 7.88 (2.34-25.4) times higher than children who get exclusive breastfeeding.

The results of interviews with mothers of children under five years who were respondents in the study, showed that the reason for mothers of toddlers did not give exclusive breastfeeding to their children was because breast milk did not come out at the time the child was born, so the baby was given formula milk as a substitute. After the breast milk is smooth, the breast milk is given to the child with formula milk added. In addition, complementary food is given earlier so the baby does not cry or fuss.

The magnitude of the effect of exclusive breastfeeding on children's nutritional status makes the WHO recommend that implementing an increase in breastfeeding interventions during the first 6 months of life as one step to achieve Global Nutrition Targets 2025 regarding the reduction in the number of stunting in children under five years (WHO, 2014).

Table 2 shows that out of 120 children, there were 37 children (30.8\%) whose birth weight was less or equal to 2500 gr. and children whose birth weight is above 2500 grams are 83 children $(69.2 \%)$. 
Table 2. Frequency Distribution of Birth Weight in Children 24-36 Months

\begin{tabular}{cccc}
\hline Number & $\begin{array}{c}\text { Birth } \\
\text { Weight }\end{array}$ & $\begin{array}{c}\text { Amount } \\
(\mathrm{N})\end{array}$ & $\begin{array}{c}\text { Percentage } \\
(\%)\end{array}$ \\
\hline 1 & $\leq 2500 \mathrm{gr}$ & 37 & 30.8 \\
\hline 2 & $>2500 \mathrm{gr}$ & 83 & 69.2 \\
\hline & Total & 120 & 100 \\
\hline
\end{tabular}

Birth weight is an indicator of a baby's growth, because it responds to stimulation, the environment, and the baby's survival. Birth weight has a large impact on a child's growth, child development and height as an adult. Babies born with a low birth weight will be at high risk of morbidity, death, infectious diseases, weight loss and stunting in the early neonatal period to childhood (Wiyogowati, 2012).

Based on the bivariate test results on the risk of low birth weight $(\leq 2500$ gr $)$ to the incidence of stunting, the OR value was 2.4. This means that children with low birth weight $(\leq$ 2500 gr) have a risk of stunting 2.4 times greater than children with normal birth weight.

Thus birth weight is a risk factor for stunting in infants aged 24-36 months at Serdang Bedagai District. The results of the study also found that in the case group there were 36 children with birth weight more $2500 \mathrm{gr}$ but stunting (60\%). This is because there are other factors that directly affect nutritional status such as infectious diseases and dietary intake, and socioeconomic factors also provide a role as other factor that influences stunting, although not directly. The results of this study are similar to other studies, which sates that the direct cause of malnutrition problems in children is the presence of infectious diseases and parasites, and inadequate consumption for their needs.

Birth weight is one indicator of health on newborn baby. Birth weight is a parameter that is often used to describe the growth of the fetus during pregnancy. Infants with low birth weight will be more vulnerable to adverse environmental influences in the future (Umboh, 2013). The Table 3 shows that out of 120 children, the number of children who have a birth length was short $(\leq 48 \mathrm{~cm})$ are 45 children $(37.5 \%)$. Whereas children who have a birth length more $48 \mathrm{~cm}$ are 75 children $(62.5 \%)$.

Table 3. Frequency Distribution of Birth Length in Children 24-36 Months

\begin{tabular}{clcc}
\hline Number & $\begin{array}{l}\text { Birth } \\
\text { Length }\end{array}$ & $\begin{array}{c}\text { Amount } \\
(\mathrm{N})\end{array}$ & $\begin{array}{c}\text { Percentage } \\
(\%)\end{array}$ \\
\hline 1 & $\leq 48 \mathrm{~cm}$ & 45 & 37.5 \\
\hline 2 & $>48 \mathrm{~cm}$ & 75 & 62.5 \\
\hline & Total & 60 & 100 \\
\hline
\end{tabular}

The length birth illustrates the linear growth of the baby during the womb. Low linear size usually indicates a poor nutritional state due to lack of energy and protein suffered in the past, which begins with slowing or retardation of fetal growth. Chi Square test results showed that there was a significant relationship between birth lengths with stunting incidence in children with OR value was 2.2. That is, toddlers with less birth length $(\leq 48 \mathrm{~cm})$ are at risk of stunting 2.2 times greater than children with normal $(>48 \mathrm{~cm})$. The results of this study are similar to other research conducted by Meilyasari and Ismawati (2014), and Anugraheni (2012), which shows that the risk of stunting is higher in children with birth length was less. The risk of failure to grow is greater in babies who have experienced prematurity. That is, birth length that is less than normal indicates the baby has experienced growth failure while in the womb. Growth failure while still in the womb indicates inadequate nutrient intake. 
In line with the results of research Dandara, et al. (2016), the OR value was 4.078. This means that toddlers with short body length at birth have a risk of stunting 4.078 times greater than toddlers with normal body length at birth. Inadequate nutrient intake in normal toddlers can cause growth failure. Low nutrient intake and infection exposure have a greater impact on growth failure in normal toddlers.

Table 4 shows bivariate analysis using the chi-square test and Fisher's modification test, the three variables studied were related to the incidence of stunting with $\mathrm{p}$ value less than 0.05 . Among the three variables, birth weight had the greatest influence on the incidence of stunting with $\mathrm{OR}=2.4$.

Table 4. Relationship between Breastfeeding History, Birth Weight and

\begin{tabular}{|c|c|c|c|c|c|c|}
\hline \multirow{2}{*}{ Variable } & \multicolumn{2}{|c|}{ Stunting } & \multicolumn{2}{|c|}{ Normal } & \multirow{2}{*}{$\begin{array}{l}\mathrm{P} \\
\text { Value }\end{array}$} & \multirow[t]{2}{*}{ OR } \\
\hline & $\mathrm{n}$ & $\%$ & $\mathrm{n}$ & $\%$ & & \\
\hline \multirow{2}{*}{\multicolumn{7}{|c|}{$\begin{array}{l}\text { Breastfeeding } \\
\text { history: }\end{array}$}} \\
\hline & & & & & & \\
\hline Exclusive & 30 & 50 & 41 & 68.3 & & \\
\hline \multicolumn{7}{|l|}{ Birth Weight } \\
\hline$\leq 2500 \mathrm{gr}$ & 24 & 40.0 & 13 & 21.7 & 0.030 & 2.4 \\
\hline$>2500 \mathrm{gr}$ & 36 & 60.0 & 47 & 78.3 & & \\
\hline \multicolumn{7}{|l|}{ Birth Length } \\
\hline$\leq 48 \mathrm{~cm}$ & 28 & 46.7 & 17 & 28.3 & 0,038 & 2.2 \\
\hline$>48 \mathrm{~cm}$ & 32 & 53.3 & 43 & 71.7 & & \\
\hline
\end{tabular}

This means that children who have a birth weight less or equal $2500 \mathrm{gr}$ have a risk of experiencing stunting 2.4 times higher than children with normal birth weight. Likewise, children who do not get exclusive breastfeeding have a risk of 2.1 times experiencing stunting events than children who get exclusive breastfeeding, and children who have a birth length less or equal 48 $\mathrm{cm}$ have a risk of 2.2 times experiencing stunting than children with normal birth lengths. Weight is an indicator of growth in the present, very sensitive to rapid changes, compared to height which illustrates the indicators of past growth.

\section{Conclusion}

Risk factors for stunting in children aged 24-36 months in Serdang Bedagai District are birth weight, breastfeeding history (exclusive), and birth length. Based on these studies it is recommended for mothers who have children under five years with low birth weight so that in the future during pregnancy more nutritious food is consumed so that mothers are not at risk of underweight (Chronic Energy Deficiency). How to deal with children who are LBW so that the growth is not hampered is the mother gives exclusive breastfeeding and complementary food in time. As well as increasing efforts to monitor the growth of children with short birth lengths by periodically measuring the length of the child's body, the implementation of which is into the activities of weighing toddlers at the post of integrated service (Posyandu). 


\section{References}

Anugraheni, H. S. (2012). Risk Factors for Stunting in children aged 12-36 months at Kecamatan Pati Kabupaten Pati. Diponegoro University, Semarang. Journal of Nutrition College, vol. 1,no.1,(2012).

Dandara, S., Hariati, L., and Ririn Teguh, Ardiansyah. 2016. Analysis of new risk factors, infant body length at birth and basic immunization history of stunting events in children aged 12-36 months in the work area Puskesmas Kandai Kota Kendari year 2016. JIMKESMAS, vol. 1, no 3 (2016).

Fikawati, S., Syafiq, Ahmad., and Karima, Khaula. 2015. Mother and Baby Nutrition. Jakarta: Rajawali Press

Kementerian Kesehatan RI. 2016. Center for Indonesian Ministry of Health Data and Information Infodatin. Toddler Short Situation. www.depkes.go.id/ resources/ download/pusdatin/.../situasi-balita-pendek-2016.pdf.

Ikatan Dokter Anak Indonesia. ASI surgery. Jakarta. Ikatan Dokter Anak Indonesia (IDAI). 2009

Meilyasari, F. and Isnawati, M. (2014). Risk factors for stunting in 12-month-old toddlers in the village Purwokerto Kecamatan Ptebon Kabupaten Kendal. Journal of Nutrition College, $3(2), 16-25$.

Permadi, M. R. et al. Risk of Early Breastfeeding Initiation and Exclusive Breastfeeding Practices Against Stunting in Children 6-24 Months. Journal of Nutrition and food Research vol 39, no 1 (2016).

RISKESDAS. (2007). Riset Kesehatan Dasar. Kementerian Kesehatan RI. Jakarta.

RISKESDAS. (2010). Riset Kesehatan Dasar. Kementerian Kesehatan RI. Jakarta.

RISKESDAS. (2013). Riset Kesehatan Dasar. Kementerian Kesehatan RI. Jakarta.

RISKESDAS. (2013). Basic Health Research of North Sumatra Province. Jakarta. From 19 Januari 2018.

RISKESDAS. (2018). Riset Kesehatan Dasar. Kementerian Kesehatan RI. Jakarta.

Supariasa, Bakri, B and Fajar, I. 2012. Assessment of Nutritional Status. Jakarta. EGC

Umboh, A. (2013). Low birth weight and blood pressure in children. Jakarta: Sagung Seto

Wiyogowati, C. (2012). Incidence of stunting in children aged under five years (0-5 months) in west Papua Province in 2010 9Analysis of Riskesdas Data in 2010).

World Health Organizatition. (2013). Childhood stunting: context causes and consequences. WHO conceptual framework. Geneva: World Health Organizatition. 2013. https://www.who.int/ nutrition/events/2013 ChildhoodStunting_colloquium_14Oct_ConceptualFramework_colour.pdf.

World Heath Organizatition (WHO). (2014). WHA global nutrition targets 2025: Stunting policy brief. Geneva: World Health Organization.

World Health Organization (WHO). (2017). Global Health Observatory (GHO). http://www.who.int/nutgrowthdb/ jme_brochure2017. pdf.

World Health Organization (WHO), (2019). Health situation and trend assessment. Stunting in Children. www.searo.who.int >nutrition_stunting -in-children. 